\title{
THE ROLE PLAYED BY THE SOUTH AFRICAN HUMAN RIGHTS COMMISSION'S ECONOMIC AND SOCIAL RIGHTS REPORTS IN GOOD GOVERNANCE IN SOUTH AFRICA
}

\section{Horsten*}

\section{Introduction}

The preamble of the South African Constitution ${ }^{1}$ contains the commitment to, amongst other things, establish a society based on democratic values, social justice and fundamental human rights, lay the foundations for a democratic and open society in which government is based on the will of the people and every citizen is equally protected by law and improve the quality of life of all citizens and free the potential of each person. One of the methods used to achieve these objectives is the inclusion of enforceable socio-economic rights in the Bill of Rights. ${ }^{2}$

Despite numerous debates surrounding the issue of enforceability of socioeconomic rights, it has become evident that these rights are indeed enforceable. Not only does section 7(2) of the Constitution place the state under an obligation to respect, protect, promote and fulfil all rights in the Bill of Rights, including socio-economic rights, but the Constitutional Court has in various decisions passed judgment on issues relating to socio-economic rights, underpinning the fact that these rights are indeed enforceable. ${ }^{3}$

* B Comm, LL B, LL M (PU for CHE); Senior Lecturer, Faculty of Law, North-West University (Potchefstroom Campus).

1 Constitution of the Republic of South Africa 1996; henceforth referred to as the Constitution.

2 Ch 2 of the Constitution.

3 See Government of the RSA v Grootboom 200011 BCLR 1169 (CC); Minister of Health v Treatment Action Campaign 20021 SA 342 (CC); Khosa v Minister of Social Development; Mahlaule v Minister of Social Development 20046 BCLR 569 (CC). 
The fact that socio-economic rights have been included in the Bill of Rights and are enforceable is, however, not sufficient to achieve the aims set out in the preamble. In order for these rights to be of any value to the people they seek to protect, they need to be implemented. ${ }^{4}$ One of the ways in which the implementation of these rights is monitored is by means of the South African Human Rights Commission's ${ }^{5}$ annual Economic and Social Rights Reports. The aim of this contribution is to assess these reports and to establish the degree to which they contribute to good governance in South Africa. ${ }^{6}$

\section{The constitutional mandate of the South African Human Rights Commission}

The Constitution establishes a number of institutions to help ensure that the rights in the Constitution become reality, one of these institutions being the South African Human Rights Commission. ${ }^{7}$ These institutions, referred to as Chapter 9 institutions, ${ }^{8}$ are independent organs with the general mandate of strengthening constitutional democracy in South Africa. ${ }^{9}$ They are independent, subject only to the Constitution and the law, and they must be impartial and must exercise their powers and perform their functions without fear, favour or prejudice. ${ }^{10}$ These institutions are accountable to the National Assembly, and must report on their activities and the performance of their functions to the Assembly at least once a year. ${ }^{11}$ Such national human rights institutions have, according to the Committee on Economic, Social and Cultural Rights, a potentially crucial role to play in promoting and ensuring the indivisibility and

See Newman 2003 SAJHR 191.

Hereafter referred to as the SAHRC.

6 This paper does not aim to interpret the SAHRC's Economic and Social Rights Reports, but merely to evaluate them in relation to which they make to good governance.

7 Other institutions include the Public Protector, the Commission for the Promotion and Protection of the Rights of Cultural, Religious and Linguistic Communities, the Commission for Gender Equality, the Auditor-General and the Electoral Commission. See Newman 2003 SAJHR 191-192.

8 By virtue of the fact that they are contained in ch 9 of the Constitution.

9 Idasa http://www.idasa.org.za/ 24 Oct 2005.

$10 \mathrm{~S}$ 181(2).

$11 \mathrm{~S}$ 181(5). 
interdependence of all human rights and it is, therefore, essential that full attention be given to economic, social and cultural rights in all of the relevant activities of these institutions. ${ }^{12}$

The SAHRC has a general mandate to monitor and assess the realisation of all human rights ${ }^{13}$ as well as a special mandate in relation to socio-economic rights. ${ }^{14}$ This additional role of the SAHRC is of great importance given South Africa's history of racial discrimination which has resulted in many South Africans suffering from socio-economic disadvantages. ${ }^{15}$ This special mandate requires of the SAHRC, each year, to require relevant organs of state to provide it with information on the measures that they have taken towards the realisation of the rights in the Bill of Rights concerning housing, ${ }^{16}$ health care,${ }^{17}$ food, ${ }^{18}$ water, ${ }^{19}$ social security, ${ }^{20}$ education ${ }^{21}$ and the environment. ${ }^{22}$ Although this special mandate merely requires of the SAHRC to require the organs of state to provide information, it would be pointless if left at that. In terms of its general mandate, it would thus appear that it is required of the SAHRC to use this information in order to monitor and assess the realisation of the rights in question.

The Constitution also makes provision for additional powers and functions of the SAHRC to be prescribed by national legislation. ${ }^{23}$ The legislation in question, the Human Rights Commission Act, ${ }^{24}$ indicates that the SAHRC must submit to the National Assembly an annual report, a report on any findings of a

12 General Comment No 10 of 1998.

S 184(1)(c).

Heyns 1998 ESR Review http://www.communitylawcentre.org.za/ 31Oct.

Reif 2000 Harvard Human Rights Journal http://www.law.harvard.edu/ 29 Mar.

Entrenched in s 26 and 28(1)(c).

Entrenched in s 27(1)(a) and 28(1)(c).

Entrenched in s 27(1)(b) and 28(1)(c).

Entrenched in s 27(1)(b).

Entrenched in s 27(1)(c) and 28(1)(c).

Entrenched in s 29.

Entrenched in s 24. The special mandate is laid down by s 184(3).

S 184(4).

Human Rights Commission Act 54 of 1994; henceforth referred to as the Human Rights Commission Act. 
serious nature and a report on an issue whenever it deems it necessary. ${ }^{25}$ According to Newman, ${ }^{26}$ a purposive reading of section 184(3) would assume that the SAHRC must use the information collected towards some form of report or assessment.

The way in which the SAHRC fulfils this function is by means of its Economic and Social Rights Reports. In these reports the SAHRC not only monitors the legislation and policies which have been adopted to realise these rights, but also the budget allocated towards realising them and the actual results of the measures. $^{27}$

\subsection{The Reporting Procedure}

The procedure which the SAHRC follows in compiling its Economic and Social Rights Reports involves, firstly, the development (and continuous fine-tuning) of protocols relating to each of the rights in question which are sent to each relevant government department. Each department must then complete the questionnaire and send it back to the SAHRC. ${ }^{28}$ The protocols are designed to provide the SAHRC with information on policy, legislative, budgetary and other measures adopted by the organ of state in question. They also include questions on vulnerable groups, problems encountered by the departments, measures taken to address these problems, indicators of progress and budgetary measures. ${ }^{29}$ The design of these protocols has been influenced by the landmark Constitutional Court decision in the Grootboom case, ${ }^{30}$ relating to the reasonableness of government's housing policies and programmes. Both

$25 \mathrm{~S}$ 15(2) of the Human Rights Commission Act.

26 Newman 2003 SAJHR 194.

27 McClain 2002 ESR Review http://www.communitylawcentre.org.za/ 31 Oct.

28 Brand and Liebenberg 2000 ESR Review http://www.communitylawcentre.org.za/ 31 Oct; McClain 2002 ESR Review http://www.communitylawcentre.org.za/ 31 Oct; Newman 2003 SAJHR 196; Liebenberg ESR Review http://www.communitylawcentre.org.za/ 31 Oct; Sithole and Nkonyane 1999 ESR Review http://www.communitylawcentre.org.za/ 31 Oct.

29 Liebenberg ESR Review http://www.communitylawcentre.org.za/ 31 Oct; Sithole and Nkonyane 1999 ESR Review http://www.communitylawcentre.org.za/ 31 Oct.

30 Government of the RSA v Grootboom 200011 BCLR 1169 (CC). 
the Grootboom and $T A C^{31}$ cases have, in essence, stated that whether or not the state has violated socio-economic rights obligations depends on whether it has implemented unreasonable policies or acted unreasonably. ${ }^{32}$

The protocols which are sent to the relevant government departments serve a dual purpose. Not only do they, according to McClain, ${ }^{33}$ generate information on the measures taken by government to realise socio-economic rights, but they also serve as a tool to raise awareness among government officials of their socio-economic rights obligations. These protocols are designed to encourage departments to set goals and benchmarks against which to measure future performance. ${ }^{34}$

The SAHRC then sets about analysing and assessing the responses received, with reference to the relevant constitutional provisions as well as international standards. ${ }^{35}$ The international standards which have been used in this process include the African Charter on Human and Peoples' Rights, ${ }^{36}$ the International Covenant on Economic Social and Cultural Rights, ${ }^{37}$ the General Comments of the Committee on Economic, Social and Cultural Rights, ${ }^{38}$ the Limburg Principles on the Implementation of the International Covenant on Economic, Social and Cultural Rights ${ }^{39}$ and the Maastricht Guidelines on Violations of Economic, Social and Cultural Rights. ${ }^{40}$

The analysis and assessment of the responses in turn leads to the production of a draft report by the SAHRC. Only once this first draft of the report has been

\footnotetext{
31 Minister of Health v Treatment Action Campaign 20021 SA 342 (CC).

32 Newman 2003 SAJHR 196.

33 McClain 2002 ESR Review http://www.communitylawcentre.org.za/ 31 Oct.

34 Ibid.

35 Kollapen 1999 ESR Review http://www.communitylawcentre.org.za/ 31 Oct; Thipanyane 1998 ESR Review http://www.communitylawcentre.org.za/ 31 Oct.

36 African (Banjul) Charter on Human and Peoples' Rights 1982.

37 International Covenant on Economic, Social and Cultural Rights adopted by the General Assembly Resolution 2200 (XXI) of 16 December 1966993 (came into operation on 3 January 1976).

38 General Comment No 1 of 1989; General Comment No 2 of 1990; General Comment No 3 of 1990; General Comment No 4 of 1991; General Comment No 5 of 1994.

39 Limburg Principles 1987 Human Rights Quarterly 122-135

40 Maastricht Guidelines 1998 Human Rights Quarterly 691-701. Kollapen 1999 ESR Review http://www.communitylawcentre.org.za/ 31 Oct.
} 
concluded is it made available to the public for comment. ${ }^{41}$ After a workshop with various interest groups, including NGO's and government departments, ${ }^{42}$ the report is completed and presented to Parliament.

\subsection{The Economic and Social Rights Reports}

The Economic and Social Rights Reports are summaries of key measures instituted by relevant organs of state. They further serve to identify some of the shortcomings of these measures. ${ }^{43}$ Each chapter of the reports, which are broken down into topical areas, ${ }^{44}$ discusses the key developments in the year in relation to socio-economic rights and contains a summary of recommendations and conclusions reached by the Commission on the measures taken by the organs of state. ${ }^{45}$

To date there have been five Economic and Social Rights Reports for different monitoring periods. The First Report, ${ }^{46}$ was published in 1998 for the 19971998 monitoring period, the Second Report, ${ }^{47}$ in 2000 for the monitoring period from April 1998 to March 1999, the Third Report, ${ }^{48}$ in 2001 for the April 1999 to

41 Thipanyane 1998 ESR Review http://www.communitylawcentre.org.za/ 31 Oct.

42 The interest groups present at the workshop held on 27 and 28 January 2004 in respect of the Fifth Report included Black Sash, Centre for Policy Studies, Centre for Education and Policy Development, Children's Institute, National Department of Agriculture, Western Cape Department of Agriculture, National Department of Education, Gauteng Department of Education, National Department of Health, Gauteng Department of Health, Limpopo Department of Health and Welfare, Free State Department of Health, Ministry of Justice, National House of Traditional Leaders, Polokwane Municipality, SA Homeless Peoples' Federation, TAC-Aids Law Project, The Presidency, Umgeni Water and the University of Venda.

43 Liebenberg ESR Review http://www.communitylawcentre.org.za/ 31 Oct.

44 These topical areas, namely housing, land, health, food, social security, education, environment, water, prisoners, finance, metros and parastatals, are based in part on government departments.

45 Liebenberg ESR Review http://www.communitylawcentre.org.za/ 31 Oct; Newman 2003 SAJHR 199.

46 SAHRC Economic and Social Rights Report; henceforth referred to as the First Report.

47 SAHRC $2^{\text {nd }}$ Economic and Social Rights Report; henceforth referred to as the Second Report.

48 SAHRC $3^{\text {rd }}$ Economic and Social Rights Report; henceforth referred to as the Third Report. 
March 2000 monitoring period, the Fourth Report, ${ }^{49}$ in 2003 for the monitoring period April 2000 to March 2002 and the Fifth Report, ${ }^{50}$ in 2004 for the April 2002 to March 2003 monitoring period. While the First Report focused largely on establishing baselines from which measurement of progressive realisation of socio-economic rights might begin, subsequent reports have focused on making recommendations based on the SAHRC's assessment of the information obtained from state organs. ${ }^{51}$

\subsection{Evaluation of the reports}

While it is widely accepted that the SAHRC has handled the mammoth task placed on it with remarkable competence, the procedure in compiling the Economic and Social Rights Reports, as well as the content of these reports, have not escaped criticism.

On the procedural side, the primary criticism leveled against the reporting process relates to the involvement of NGO's and civil society in the drafting of the reports. The SAHRC does not make the government information obtained in its protocols available before the production of its draft report. The reason for this is that the SAHRC is of the opinion that the release of these documents to the public before they have been analysed and evaluated by the SAHRC would be in bad faith. ${ }^{52}$ Because these documents are furnished to the SAHRC in terms of a specific constitutional mandate, the SAHRC has expressed concern that the premature release of this information could have a negative effect on the relationship which it is trying to develop with government departments. ${ }^{53}$

49 SAHRC $4^{\text {th }}$ Economic and Social Rights Report; henceforth referred to as the Fourth Report.

50 SAHRC $5^{\text {th }}$ Economic and Social Rights Report; henceforth referred to as the Fifth Report.

51 See Newman 2003 SAJHR 195.

52 Thipanyane 1998 ESR Review http://www.communitylawcentre.org.za/ 31 Oct.

53 Brand and Liebenberg 2000 ESR Review http://www.communitylawcentre.org.za/ 31 Oct; Thipanyane 1998 ESR Review http://www.communitylawcentre.org.za/ 31 Oct. 
While this argument on the side of the SAHRC has merit, there are nevertheless various arguments to be made for the earlier involvement of NGO's and civil society, the first one relating to the issue of resources. It is a well-known fact that the SAHRC faces serious resource constraints and has had to rely on donor funding for the reporting process. ${ }^{54}$ At one point the SAHRC officially informed the Minister of Finance that it would be unable to carry out its functions relating to certain statutory mandates and the section 184(3) requirement for annual reporting on social and economic rights. ${ }^{55}$ Where a monitoring body such as the SAHRC does not have sufficient resources at its disposal, it is not able to obtain all information that could be available. ${ }^{56}$ Allowing NGO and civil society participation at an earlier stage of the process could provide the SAHRC with additional information and experience, free of charge. There are many well-funded and highly specialised NGO's in South Africa which could make an invaluable contribution to the reports and, consequently, to the promotion of the realisation of socio-economic rights in this country. ${ }^{57}$

A second argument for the earlier involvement of NGO's and civil society has to do with the fact that this could lead to the SAHRC gaining a more realistic picture of issues relating to the realisation of socio-economic rights in South Africa. ${ }^{58}$ When responding to the SAHRC's protocols, government departments would obviously not want to encourage criticism of themselves and would consequently not want to highlight the kind of information that would reveal socio-economic rights violations. This could, as has occurred in the international monitoring context, result in government's version of the facts not corresponding with reality. ${ }^{59}$ NGO's, if granted access to the information

54 See Reid 2000 Harvard Human Rights Journal 68.

55 Some of the more recent Economic and Social Rights Reports have had to begin by thanking the Canadian, Finnish and Norwegian governments for funding. Newman 2003 SAJHR 210. See also McClain 2002 ESR Review http://www.communitylawcentre.org.za/ 31 Oct; Brand and Liebenberg 2000 ESR Review http://www.communitylawcentre.org.za/ 31 Oct.

56 Newman 2003 SAJHR 211.

57 See Heyns 1998 ESR Review http://www.communitylawcentre.org.za/ 31Oct.

58 See Brand 1999 ESR Review http://www.communitylawcentre.org.za/ 31 Oct.

59 Newman 2003 SAJHR 213. 
provided to the SAHRC by government departments, can provide alternative information which the SAHRC can use to verify the government reports as well as their own evaluation of government programmes and policies. ${ }^{60}$ The benefit here is that NGO's send workers out into communities and are able to assess the realisation of socio-economic rights at grassroots level. ${ }^{61}$ In this way NGO monitoring can complement the government reports. ${ }^{62}$

Finally, reference can be made to the international monitoring process by international treaty monitoring bodies. It is common cause that the role of NGO's has been extremely important in ensuring the success of international reporting mechanisms. ${ }^{63}$ According to Alston, ${ }^{64}$ the critical need for supervisory bodies to have access to alternative sources of information when examining and evaluating reports received from government is clearly demonstrated in the experience of the various United Nations human rights organs. ${ }^{65}$ Should the SAHRC allow NGO's access to the information provided by government soon after it has been submitted, NGO's will have sufficient time to submit alternative reports, ${ }^{66}$ which could be considered by the SAHRC along with the information provided by government. This will more closely resemble the process as it occurs at international level, whereby treaty monitoring bodies, in considering reports of states parties, welcome the information provided by NGO's about human rights practices around the world. ${ }^{67}$ At international level, NGO's often

60 Brand and Liebenberg 2000 ESR Review http://www.communitylawcentre.org.za/ 31 Oct; Newman 2003 SAJHR 214.

61 The data gathered by the SAHRC through the protocols is obtained from government departments at national and provincial level, but not at local level. Reports from NGO's often reflect the socio-economic situation as experienced by individuals at local level, which could assist the SAHRC in obtaining a better all-round picture. See Brand and Liebenberg 2000 ESR Review http://www.communitylawcentre.org.za/ 31 Oct; Newman 2003 SAJHR 211.

62 Newman 2003 SAJHR 214.

63 See Heyns 1998 ESR Review http://www.communitylawcentre.org.za/ 31Oct.

64 As quoted by Heyns 1998 ESR Review http://www.communitylawcentre.org.za/ 31Oct.

65 The SAHRC has been called on by various organisations, including COSATU, Black Sash and SANGOCO, to make the information provided by government departments available to them for comment.

See Heyns 1998 ESR Review http://www.communitylawcentre.org.za/ 31Oct.

66 Commonly referred to as "shadow" reports.

67 See Amnesty International http://web.amnesty.org/ 29 Mar; Heyns 1998 ESR Review http://www.communitylawcentre.org.za/ 310ct; Schnabel and Horowitz http://www.tolerance-net.org/ 29 Mar. 
provide treaty monitoring bodies with the only alternative information, which accurately reflects the situation in a country, to a state party's report. ${ }^{68}$

Regarding the content of the reports, the primary criticism revolves around the extent of substantive assessment of the information in the reports. ${ }^{69}$ The SAHRC was, in respect of both the First and Second Reports, for example, criticised for collecting and disseminating information without offering much assessment of the information. ${ }^{70}$ While the Third Report accepted some of this criticism and expressed aspirations to further assessment, the Fourth and Fifth Reports have to a degree resolved this problem by offering numerous independent critiques and recommendations. ${ }^{71}$

Another criticism of the reports relates to the SAHRC's failure to make use of a 'minimum core obligation' approach. ${ }^{72}$ According to the United Nations Committee on Economic, Social and Cultural Rights, a state party in which any significant number of individuals is deprived of essential foodstuffs, of essential primary health care, of basic shelter and housing, or of the most basic forms of education is prima facie failing to discharge its obligations. While this approach was rejected in both the Grootboom ${ }^{73}$ and $T A C^{74}$ cases, it was recommended by the Committee of Inquiry into a Comprehensive System of Social Security for South Africa, which is of the opinion that the court may use this minimum core if there is a specific infringement or non-compliance with a social security

68 Amnesty International http://web.amnesty.org/ 29 Mar. An example of an NGO which functions at international level is the NGO Group for the Convention on the Rights of the Child, which is a coalition of international non-governmental organisations which work together to facilitate the implementation of the United Nations Convention on the Rights of the Child. This NGO manages the Alternative Reports that have been submitted by national NGO's to the Committee on the Rights of the Child. See CRIN http://www.crin.org/ 29 Mar.

69 Newman 2003 SAJHR 201.

70 Newman 2003 SAJHR 195.

71 Newman 2003 SAJHR 195.

72 As referred to by the United Nations Committee on Economic, Social and Cultural Rights General Comment No 3 of 1990 at par 9.

73 Grootboom case par 33.

74 TAC case par 33-34. 
right. ${ }^{75}$ In the context of the obligations laid down by United Nations Committee on Economic, Social and Cultural Rights, it is submitted that the court's approach to the minimum core obligation approach falls short of international law. $^{76}$

The SAHRC, as a mechanism for the domestic implementation of international human rights obligations, ${ }^{77}$ should consider making use of the minimum core obligation approach. Newman ${ }^{78}$ is of the opinion that the fact that this approach has been rejected by the courts does not mean that the approach should be rejected by the SAHRC and provides a convincing argument that some core content of socio-economic rights must remain relevant for the SAHRC as a practical matter. According to this argument, the SAHRC cannot simply evaluate 'reasonableness' without considering this reasonableness in relation to something. ${ }^{79}$ Although the case law in question is not helpful in the development of a minimum core, Newman ${ }^{80}$ argues that the influence might be able to flow in the other direction, in that SAHRC reporting on something tangible might make information available from which the court could eventually derive a minimum core that could in turn influence case law.

\section{The role of the SAHRC's reports in the promotion of good governance}

The concept of good governance is increasingly being accepted as the standard for domestic governance. ${ }^{81}$ According to Mafunisa, ${ }^{82}$ governance

75 By implication it will also be applicable in the case of infringement on any socio-economic right. Committee of Inquiry Transforming the Present. See Scott and Alston 2000 SAJHR 256.

76 According to s 39(1)(c) of the Constitution, when interpreting the Bill of Rights, a court, tribunal or forum must consider international law. According to s 233, when interpreting any legislation, every court must prefer any reasonable interpretation of the legislation that is consistent with international law over any alternative interpretation that is inconsistent with international law.

77 Reid 2000 Harvard Human Rights Journal 3.

78 See Newman 2003 SAJHR 197-198.

79 Ibid 197.

80 Ibid 198.

81 Reid 2000 Harvard Human Rights Journal 16. 
includes the exercise of political power for directing and regulating socioeconomic affairs. Although no generally accepted definition of good governance exists, it can be broadly defined as the responsible use of political authority to manage a nation's affairs. ${ }^{83}$ It is understood to consist of various components, including ensuring the rule of law (and in the South African context, obviously, ensuring that governance complies with the Constitution), improving the efficiency and accountability of the public sector, tackling corruption, effectively protecting human rights and allowing for participation by the people in such governance. ${ }^{84}$ The public needs to be able to participate, not only through elected representatives (parliament) and non-elected actors (political parties and public interest groups), but also directly. ${ }^{85}$ Public accountability, according to Hilliard and Kemp, ${ }^{86}$ implies that public functionaries have to provide explanations to justify positive or negative results obtained in the performance of their daily activities. Good governance must be both substantive and procedural. ${ }^{87}$ In other words, it must exist not only in respect of aims and results, but also in respect of procedures and is of little use if it is not accompanied by socio-economic progress. $^{88}$ It needs to have a strong preventive aspect, giving society sound structures for economic and social development. $^{89}$

In order to comply with the principle of good governance, attention to socioeconomic rights is thus imperative. Government action in this regard needs to be compliant with its constitutional obligations and government needs to be held accountable to the people. The people who are protected by the inclusion of socio-economic rights in the Constitution need to be in a position to both

82 Mafunisa 2004 International Review of Administrative Sciences 489.

83 Reid 2000 Harvard Human Rights Journal 16.

84 See Hilliard and Kemp 1999 Politeia 41; Ramsamy http://www.chr.up.ac.za/ 25 Oct; Reagan 2002 South African Journal of International Affairs 190; Reid 2000 Harvard Human Rights Journal 16-18. Van Gerven European Union 158 describes good governance as "the exercise of public power to pursue objectives and attain results in the interest of the people through a variety of regulative and executive processes".

85 Van Gerven European Union 234.

86 Hilliard and Kemp 1999 Politeia 43.

87 Reid 2000 Harvard Human Rights Journal 18.

88 See Ramsamy http://www.chr.up.ac.za/ 25 Oct; Van Gerven European Union 171.

89 Reid 2000 Harvard Human Rights Journal 17. 
make themselves heard on the issue of the realisation (or non-realisation) of their rights and to be able to enforce these rights.

The Constitution allows for this in various ways. Firstly, it grants everyone the right to access to courts. ${ }^{90}$ In this way, people are able to have their socioeconomic rights enforced. In the Grootboom judgment, for example, the right to have access to the courts, along with other substantive rights, ${ }^{91}$ resulted in an evaluation by the Constitutional Court of the constitutionality of government's housing programmes. This gave rise to a finding that the programmes were not reasonable and an order forcing government to comply with its constitutional obligations in respect of access to adequate housing.

Another way in which the society can contribute towards good governance in respect of socio-economic rights is through the complaints process established under the Human Rights Commission Act. Anyone whose rights have been violated can (either themselves or through somebody else) lodge a complaint with the SAHRC which will be investigated. ${ }^{92}$ Such a complaint is lodged and investigated free of charge, making it more accessible than approaching the courts, where litigation can become a costly process. ${ }^{93}$ The SAHRC has the power to take steps to secure appropriate redress where it finds that human rights have been violated. ${ }^{94}$ In this way, the SAHRC acts as a mechanism for public participation in the regulation of the conduct of the public administration. ${ }^{95}$ This allows the public to contribute towards good governance in respect of socio-economic rights, by making use of a Chapter 9 institution.

While judicial processes and individual complaints are important means of enforcement, they are often inadequate. Vulnerable groups (and individuals) are less likely to be able to access these processes for various reasons,

90 S 34 and 38 of the Constitution.

91 The right to have access to adequate housing (s 26(1) of the Constitution) and the child's right to shelter (s 28(1)(c) of the Constitution).

92 Information on the complaint process and the complaint form can be accessed at SAHRC http://www.sahrc.org.za/ 26 Jul. See Reid 2000 Harvard Human Rights Journal 7, 18.

93 Reid Harvard Human Rights Journal 7.

$94 \mathrm{~S}$ 184(2)(b) of the Constitution.

95 Reid 2000 Harvard Human Rights Journal 18. 
including lack of knowledge of the processes available to them and financial constraints. ${ }^{96}$ While these processes address the specific violation in question, they do not easily offer a means of addressing deeper systematic problems. ${ }^{97}$ One way in which these problems can indirectly be addressed is through the SAHRC's Economic and Social Rights Reports. The reports promote accountability of the relevant organs of state by making them report to the SAHRC on policy, legislative, budgetary and other measures which were adopted as a means towards the realisation of socio-economic rights. In this way the SAHRC plays an overseeing and monitoring role in ensuring transparency and accountability of government departments. ${ }^{98}$ As already mentioned, the process of reporting to the SAHRC encourages departments to set goals and benchmarks against which to measure future performance. ${ }^{99}$

While it is clear that the SAHRC's reports go a long way to promoting good governance in respect of socio-economic rights, it is also clear that there are ways in which these reports could assist in good governance to an even greater degree. Good governance allows for the maximum degree of citizen participation. ${ }^{100}$ While individuals are allowed to approach the courts or make use of the complaints process, many do not do so. Their voices are, however, made heard by NGO reports which discuss the socio-economic situation at grassroots level, often referring the plights faced by individuals. It is thus evident that allowing a greater degree of (and earlier) participation by civil society, including NGO's, in the drafting of the reports would give the SAHRC a clearer and more representative picture of the socio-economic situation as experienced by individuals in South Africa. This would, in turn, by making the socio-economic problems faced by individuals who would otherwise not have a voice heard, constitute yet another positive step towards good governance in South Africa, especially insofar as it pertains to the realisation of socioeconomic rights.

96 See Newman 2003 SAJHR 214; Reid 2000 Harvard Human Rights Journal 3, 7.

97 Newman 2003 SAJHR 214.

98 Ramsamy http://www.chr.up.ac.za/ 25 Oct; Reid 2000 Harvard Human Rights Journal 19.

99 McClain 2002 ESR Review http://www.communitylawcentre.org.za/ 31 Oct.

100 See Hilliard and Kemp 1999 Politeia 41; Reagan 2002 South African Journal of International Affairs 190; Van Gerven European Union 158-159. 


\section{Conclusion}

The SAHRC, as a Chapter 9 institution, plays an extremely important role in the monitoring and assessment of the realisation of socio-economic rights in South Africa. The Economic and Social Rights Reports of the SAHRC serve as the primary measure in the fulfillment of its constitutional obligations and despite various criticisms which can be leveled against both the reporting procedures and the contents of the reports, have thus far been relatively successful in the evaluation of government's activities relating to this mandate.

The role of the reports in the promotion of good governance in respect of the realisation of socio-economic rights could, however, be improved. The primary manner in which this could be done is by allowing for a greater degree of participation of civil society and NGO's in the drafting of these reports, thereby ensuring the maximum degree of public participation, which is one of the cornerstones of good governance. 


\section{Bibliography}

Committee of Inquiry Transforming the Present

Committee of Inquiry into a Comprehensive System of Social Security for South Africa Transforming the Present - Protecting the Future:

Consolidated Report (The Committee Pretoria 2002)

Hilliard and Kemp 1999 Politeia

Hilliard VG and Kemp ND "Citizen Participation Crucial to Good

Governance and Administration in South Africa" 1999 Politeia 40-67

Limburg Principles 1987 Human Rights Quarterly

"The Limburg Principles on the Implementation of the International

Covenant on Economic, Social and Cultural Rights" 1987 (9) Human Rights

Quarterly 122-135

Maastricht Guidelines 1998 Human Rights Quarterly

"The Maastricht Guidelines on Violations of the International Covenant on

Economic, Social and Cultural Rights" 1998 (20) Human Rights Quarterly 691-701

Mafunisa 2004 International Review of Administrative Sciences Mafunisa MJ "The Role of Civil Society in Promoting Good Governance in the Republic of South Africa" 2004 International Review of Administrative Sciences 489-496

Newman 2003 SAJHR

Newman DG "Institutional Monitoring of Social and Economic Rights: A South African Case Study and a New Research Agenda" 2003 SAJHR 189-216

Reagan 2002 South African Journal of International Affairs

Reagan OR "NEPAD and Good Governance" 2002 South African Journal of International Affairs 189-192 
SAHRC Economic and Social Rights Report

South African Human Rights Commission Economic and Social Rights

Report 1997-1998 (SAHRC Johannesburg 1998)

SAHRC $2^{\text {nd }}$ Economic and Social Rights Report

South African Human Rights Commission $2^{\text {nd }}$ Economic and Social Rights Report 1998-1999 (SAHRC Johannesburg 2000)

SAHRC $3^{\text {rd }}$ Economic and Social Rights Report

South African Human Rights Commission $3^{\text {rd }}$ Economic and Social Rights

Report 1999-2000 (SAHRC Johannesburg 2001)

SAHRC $4^{\text {th }}$ Economic and Social Rights Report

South African Human Rights Commission $4^{\text {th }}$ Economic and Social Rights

Report 2000-2002 (SAHRC Johannesburg 2003)

SAHRC $20045^{\text {th }}$ Economic and Social Rights Report

South African Human Rights Commission $5^{\text {th }}$ Economic and Social Rights

Report 2002-2003 (SAHRC Johannesburg 2004)

Scott and Alston 2000 SAJHR

Scott $\mathrm{C}$ and Alston $\mathrm{P}$ "Adjudicating constitutional priorities in a transitional context: a comment on Soobramoney's legacy and Grootboom's promise" 2000 SAJHR 207-268

Van Gerven European Union

Van Gerven W The European Union: A Polity of States and Peoples (Hart Publishing Oregon 2005) 


\section{Treaties and other international sources}

African (Banjul) Charter on Human and Peoples' Rights OAU Doc

CAB/LEG/73/3rev 5, 21 ILM 581982

General Comment No 1 Reporting by States Parties UN Doc E/1989/22 1989

General Comment No 2 International technical assistance measures (Article 22 of the Covenant) UN Doc E/1990/23 1990

General Comment No 3 The nature of States Parties obligations (Article 2(1) of the Covenant UN Doc E/1991/23 1990

General Comment No 4 The right to adequate housing (Article 11(1) of the Covenant) UN Doc E/1992/23 1991

General Comment No 5 People with disabilities UN Doc E/C12/1994/13 1994

General Comment No 10 The role of the national human rights institutions in the protection of economic, social and cultural right UN Doc E/C 12/1998/25 1998

International Covenant on Economic, Social and Cultural Rights adopted by the General Assembly Resolution 2200 (XXI) of 16 December 19669931976 United Nations Convention on the Rights of the Child 1990

\section{Register of legislation}

Constitution of the Republic of South Africa 1996

Human Rights Commission Act 54 of 1994

\section{Register of cases}

Government of the Republic of South Africa and Others v Grootboom and Others 200011 BCLR 1169 (CC)

Khosa and Others v Minister of Social Development and Others; Mahlaule and Another v Minister of Social Development and Others 20046 BCLR 569 (CC)

Minister of Health and Others v Treatment Action Campaign and Others 20021 SA 342 (CC) 


\section{Register of Internet resources}

Amnesty International http://web.amnesty.org/ 29 Mar

Amnesty International 2002 The Role of Civil Society [Found on internet] http://web.amnesty.org/pages/treaty-ngo-eng [Date of use 29 Mar 2006]

Brand 1999 ESR Review http://www.communitylawcentre.org.za/ 31 Oct Brand D "The SA Human Rights Commission First Economic and Social Rights Report" 1999 ESR Review [Found on internet] http://www.communitylawcentre.org.za/ser/esr1999/1999jul 1streport. php [Date of use 31 Oct 2005]

Brand and Liebenberg 2000 ESR Review http://www.communitylawcentre.org.za/ 31 Oct Brand D and Liebenberg $S$ "The South African Human Rights Commission The Second Economic and Social Rights Report" 2000 ESR Review [Found on internet] http://www.communitylawcentre.org.za/ser/esr2000/2000sept report. php [Date of use 31 Oct 2005]

CRIN http://www.crin.org/ 29 Mar

Child Rights Information Network 2006 NGO Group for the Convention on the Rights of the Child [Found on internet] http://www.crin.org/NGOGroupforCRC/ [Date of use 29 Mar 2006]

Heyns 1998 ESR Review http://www.communitylawcentre.org.za/ 310ct Heyns C "Update on the SA Human Rights Commission Switching on the NGO Monitor Screens" 1998 ESR Review [Found on internet] http://www.communitylawcentre.org.za/ser/esr1998/1998june sahrcupdate. php [Date of use 31Oct 2005]

Idasa http://www.idasa.org.za/ 24 Oct 2005 Institute for a Democratic Alternative in South Africa 2004 What are the 
Chapter 9 institutions? [Found on internet] http://www.idasa.org.za/faqs details.asp?RID=76 [Date of use 24 Oct 2005]

Kollapen 1999 ESR Review http://www.communitylawcentre.org.za/ 31 Oct Kollapen J "Monitoring Socio-Economic Rights: What has the SA Human Rights Commission Done?" 1999 ESR Review [Found on internet] http://www.communitylawcentre.org.za/ser/esr1999/1999march kollapen.php [Date of use 31 Oct 2005]

Liebenberg ESR Review http://www.communitylawcentre.org.za/ 31 Oct Liebenberg S "The SAHRC's Fourth Report on Socio-Economic Rights" September 2003 ESR Review 15 [Found on Internet] http://www.communitylawcentre.org.za/ser/esr2003/2003sept report.php [Date of use 31 Oct 2006]

McClain 2002 ESR Review http://www.communitylawcentre.org.za/ 31 Oct McClain CV "The SA Human Rights Commission and Socio-Economic Rights Facing the Challenges" 2002 ESR Review [Found on internet] http://www.communitylawcentre.org.za/ser/esr2002/2002july commission.php [Date of use 31 Oct 2005]

Ramsamy http://www.chr.up.ac.za/ 25 Oct Ramsamy P 2002 Good governance in the Southern African Development Community [Found on internet] http://www.chr.up.ac.za/centre publications/occ papers/occ14.html [Date of use 25 Oct 2005]

Reif 2000 Harvard Human Rights Journal http://www.law.harvard.edu/ 29 Mar Reif LC "Building Democratic Institutions: The Role of National Human Rights Institutions in Good Governance and Human Rights Protection" 2000 Harvard Human Rights Journal 1-69 [Found on internet] http://www.law.harvard.edu/students/orgs/hrj/iss13/reif.shtml [Date of use 29 Mar 2006] 
Schnabel and Horowitz http://www.tolerance-net.org/ 29 Mar

Schnabel A and Horowitz S 2002 NGOs' critical role in advancing human rights in transition societies [Found on internet] http://www.tolerancenet.org/news/podium/podium071.html [Date of use 29 Mar 2006]

Sithole and Nkonyane 1999 ESR Review

http://www.communitylawcentre.org.za/ 31 Oct

Sithole B and Nkonyane Z "Monitoring Socio-Economic Rights The SA

Human Rights Commission's Second Annual Cycle" 1999 ESR Review

[Found on internet]

http://www.communitylawcentre.org.za/ser/esr1999/1999nov monitoring.ph

p [Date of use 31 Oct 2005]

Thipanyane 1998 ESR Review http://www.communitylawcentre.org.za/ 31 Oct Thipanyane T "The SA Human Rights Commission" 1998 ESR Review [Found on internet]

http://www.communitylawcentre.org.za/ser/esr1998/1998oct sahrc.php [Date of use 31 Oct 2005]

SAHRC http://www.sahrc.org.za/ $26 \mathrm{Jul}$ South African Human Rights Commission 2002 Complaint Information [Found on internet] http://www.sahrc.org.za/sahrc cms/publish/cat index 29.shtml [Date of use 26 Jul 2006] 